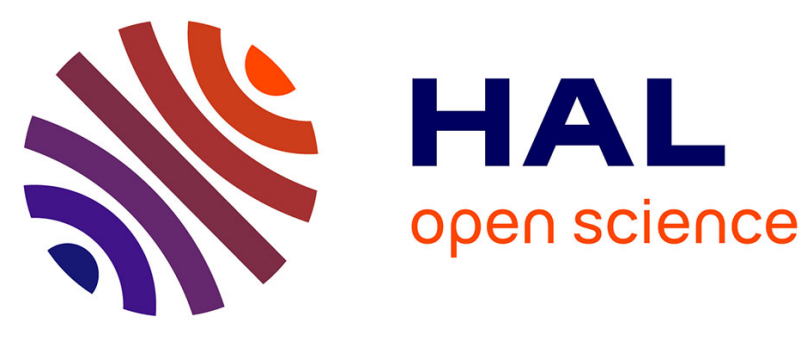

\title{
How does stocking rate influence horse behaviour, performances and pasture biodiversity in mesophile grasslands?
}

Géraldine Fleurance, Anne A. Farruggia, Laurent Lanore, Bertrand Dumont

\section{- To cite this version:}

Géraldine Fleurance, Anne A. Farruggia, Laurent Lanore, Bertrand Dumont. How does stocking rate influence horse behaviour, performances and pasture biodiversity in mesophile grasslands?. Agriculture, Ecosystems and Environment, 2016, 231, pp.255-263. 10.1016/j.agee.2016.06.044 . hal02634659

\section{HAL Id: hal-02634659 \\ https://hal.inrae.fr/hal-02634659}

Submitted on 27 May 2020

HAL is a multi-disciplinary open access archive for the deposit and dissemination of scientific research documents, whether they are published or not. The documents may come from teaching and research institutions in France or abroad, or from public or private research centers.
L'archive ouverte pluridisciplinaire HAL, est destinée au dépôt et à la diffusion de documents scientifiques de niveau recherche, publiés ou non, émanant des établissements d'enseignement et de recherche français ou étrangers, des laboratoires publics ou privés.

\section{다(1)(2)}

Distributed under a Creative Commons Attribution - ShareAlikel 4.0 International 


\title{
How does stocking rate influence horse behaviour, performances and pasture biodiversity in mesophile grasslands?
}

\author{
Géraldine Fleurance $^{\mathrm{a}, \mathrm{b}, \mathrm{c}, *}$, Anne Farruggia ${ }^{\mathrm{b}, \mathrm{c}}$, Laurent Lanore $^{\mathrm{b}, \mathrm{c}}$, Bertrand Dumont $^{\mathrm{b}, \mathrm{c}}$ \\ a IFCE, Direction Développement et Recherche, 49411 Saumur, France \\ b INRA, UMR1213 Herbivores, 63122 Saint-Genès-Champanelle, France \\ c VetAgro Sup, UMR1213 Herbivores, 63370 Lempdes, France
}

\section{A R T I C L E IN F O}

\section{Article history:}

Received 22 February 2016

Received in revised form 22 June 2016

Accepted 30 June 2016

Available online 18 July 2016

\section{Keywords:}

Permanent grassland

Grazing intensity

Sward heterogeneity

Diet selection

Carabidae

Grasshoppers

\begin{abstract}
A B S T R A C T
Reducing grazing intensity is widely recommended as a strategy to increase grassland biodiversity through greater sward heterogeneity. Horses are playing an increasing role in the management of permanent grasslands across Europe, but the effects of horse grazing under contrasting stocking rates have been poorly studied. Here we describe the effects of two contrasted stocking rates ("High" 1.8 $\mathrm{LU} \mathrm{ha}^{-1}$ vs. "Moderate" $1.1 \mathrm{LU} \mathrm{ha}^{-1}$ ) on sward structure, horse foraging behaviour and performances, and pasture biodiversity in a mesophile grassland of central France. Horses selectively grazed vegetative patches of high nutritive value, especially at the moderate stocking rate $(\mathrm{p}<0.01)$. This enabled them to maintain diet quality (diet dry matter digestibility: 59\% DM) and performances (daily liveweight gain > 270 g animal $^{-1} \mathrm{~d}^{-1}$ ) at the same level in highly and moderately grazed plots despite contrasted herbage biomass and quality. Horses, with their two sets of incisors, created and maintained patches of short grass in a matrix of tall vegetation in both treatments. Consequently, sward structural heterogeneity did not significantly differ between highly and moderately grazed plots, and there was no detectable effect of grazing intensity on floristic and arthropod diversity over the four-year study. The two stocking rates did however result in a divergent evolution of legumes for which abundance increased at the high stocking rate $(\mathrm{p}<0.05)$. Abundance of Carabidae and grasshoppers from tall grasslands was higher at the moderate stocking rate $(\mathrm{p}<0.05)$. We conclude that decreasing stocking rate would only have a marginal effect on grassland biodiversity, while farm performance will be strongly affected by the decrease in the number of horses per unit area.
\end{abstract}

(c) 2016 Elsevier B.V. All rights reserved.

\section{Introduction}

Permanent grasslands are recognized as an important source of biodiversity across Europe, making it essential to develop and promote grazing management that prioritizes ecosystem integrity as much as livestock production. Several studies report how reducing grazing intensity in semi-natural grasslands can increase plant diversity as a result of reduced disturbance and higher sward heterogeneity (Dumont et al., 2009; Klimek et al., 2007; Marriott et al., 2004). Moderate grazing intensity also benefits butterflies, grasshoppers and ground-dwelling arthropods by providing a greater number of ecological niches (Dumont et al., 2009; Kruess

\footnotetext{
* Corresponding author at: INRA Centre de recherches Auvergne Rhône-Alpes, UMR1213 Herbivores, 63122 Saint-Genès-Champanelle, France.

E-mail addresses: geraldine.fleurance@clermont.inra.fr (G. Fleurance), anne.farruggia@clermont.inra.fr (A. Farruggia), laurent.lanore@clermont.inra.fr (L. Lanore), bertrand.dumont@clermont.inra.fr (B. Dumont).
}

and Tscharntke, 2002; Wallis de Vries et al., 2007). Grazing intensity further determines vegetation biomass and herbage quality along the grazing season. Applying a high stocking rate maintains herbage quality in homogeneous swards by limiting reproductive stem growth and herbage senescence (Garcia et al., 2003; Parsons and Chapman, 1999). In contrast, when stocking rate is decreased, the imbalance between herbage offer and animal intake leads to a coexistence of short vegetative patches in grazed areas and under-grazed vegetation with high biomass accumulation including dead leaves and low-digestibility stems (Isselstein et al., 2003; Marriott et al., 2005; White et al., 2004).

of all the large domestic herbivores, horses are the most likely to create and maintain patches of short grass that they preferentially graze within a matrix of tall vegetation in which they concentrate their faeces (Loucougaray et al., 2004; Ménard et al., 2002; Ödberg and Francis-Smith, 1977). This behaviour has long been interpreted as an anti-parasite strategy (Taylor, 1954) but recent studies suggest that the selection of short high-quality 
patches by horses could also be explained as a strategy designed to maximize digestible protein intake (Edouard et al., 2010; Fleurance et al., 2005). Despite the increasing numbers of horses grazing permanent grasslands across Europe (European Horse Network, 2010), few studies have investigated the effects of horse grazing under contrasting stocking rates on diet selection and sward structure. Moreover, these studies have focused on grazeland of high nature value (Cornelissen and Vulink, 2015; Magnússon and Magnússon, 1990; Nolte et al., 2013, 2014) and not on the mesophile grasslands most commonly used in horse production systems. In addition, general trends in the impact of horses on grassland diversity have mainly come from comparisons between grazed and ungrazed areas (Duncan, 1992; Holmquist et al., 2010, 2013; Hoste-Danylow et al., 2010; Ten Harkel and Van der Meulen, 1995) or with other herbivore species (Catorci et al., 2012; Loucougaray et al., 2004; Öckinger et al., 2006; Rosa Garcia et al., 2013; Vulink et al., 2000).

In the present study, we simultaneously analyze the effects of two contrasting stocking rates ("High" vs. "Moderate") on sward structure, horse foraging behaviour and performances, and pasture biodiversity in a hill-range mesophile grassland of central France. We analyzed how horses adapt their foraging behaviour in response to variations in sward availability and quality and investigated whether they can maintain diet quality and performance as grazing intensity decreases. We hypothesize that the strong selection of short high quality patches by horses will create strong sward structural heterogeneity at both stocking rates, and therefore buffer the benefits of reducing grazing intensity on grassland biodiversity.

\section{Materials and methods}

\subsection{Experimental design}

The study was carried out in a mesophile grassland of central France (French Horse and Riding Institute experimental farm station in Chamberet, $01^{\circ} 43^{\prime} 14^{\prime}-45^{\circ} 35^{\prime} 03^{\prime \prime}$, $440 \mathrm{~m}$ a.s.l.) over four grazing seasons from 2006 to 2009. Climate is oceanic and soil is episkeletic podzol (http://eusoils.jrc.ec.europa.eu/). Precipitation fluctuated strongly along the study from $1104 \mathrm{~mm}$ in 2009$1437 \mathrm{~mm}$ in 2008. Plots had been intensively managed for rotational grazing by horses for many years, which explains their relatively low botanical diversity with a total of 48 plant species recorded over the whole area (16.2 ha) in 2006. Two stocking rates were compared: a high stocking rate $\left(1.8 \mathrm{LU} \mathrm{ha}^{-1} ; 1 \mathrm{LU}=600 \mathrm{~kg}\right.$ liveweight) designed to have most of the edible biomass consumed at the end of the grazing season, and a moderate stocking rate (1.1 LU ha ${ }^{-1}$ ). Six 2.7-ha plots were created within the pasture, so that each treatment was replicated three times in a randomized block design. At the high stocking rate, five horses were continuously grazed in each plot from mid-April to end of July then from early September to early November, while at the moderate stocking rate, three horses grazed each plot during the same periods. Horses were removed from experimental pastures from the end of July to early September to avoid pasture degradation at the high stocking rate. They were thus kept together in another permanent grassland, or indoors in severe summer drought.

Anglo-Arab and French saddle breeds ( $3.2 \pm 0.1$ years old, $521.7 \pm 6.5 \mathrm{~kg}$ ) were used each year. At the start of each grazing season, the six groups of horses were balanced for body size, body condition score, breed, sex, age, and previous feeding experience.

Sward measurements and behavioural observations were carried out in each plot from 2006 to 2008 at three periods along the grazing season: spring (early May) before flowering of major sward components, summer (end of June) when sward heterogeneity is expected to be at a maximum and autumn (October) to account for cumulative effects of treatments. Sward botanical diversity was measured in June 2006 and 2009, and insect diversity was recorded each summer, in June for grounddwelling arthropods and in July for grasshoppers.

\subsection{Sward measurements}

Sward height was measured on parallel transects covering the entire plot (about 500 sample points per plot) at the first place where a stick contacted the undisturbed sward surface. The coefficient of variation (CV) was then used as an indicator of sward heterogeneity (Eschen et al., 2012). At each sample point, we also recorded vegetation stage (vegetative, reproductive or dead), dominant botanical family (grass, legumes or forbs), distinguished between pure and mixed potential bites, and recorded bare ground gaps and the presence of faeces.

Herbage biomass was determined for four sward types, i.e. vegetative short patches (VS, $\leq 4 \mathrm{~cm}$ ), vegetative intermediate (VI, $5-8 \mathrm{~cm}$ ), vegetative tall $(\mathrm{VT}, \geq 9 \mathrm{~cm})$, reproductive and dead vegetation (Repro/Dead), by randomly cutting six $0.5 \mathrm{~m}^{2}(10 \mathrm{~cm}$ $\times 5 \mathrm{~m}$-long) strips to ground level in each sward type and plot. Quality of herbage offered was assessed for each sward type (VS, VI, VT, Repro/Dead) from three biomass samples randomly selected among these six. Samples were dried at $60^{\circ} \mathrm{C}$ to constant weight and analyzed for crude protein (CP; Kjeldahl method $\mathrm{N} \times 6.25)$ and fibre content (NDF: neutral detergent fiber according to the method of Van Soest et al., 1991). Mean biomass per plot and mean herbage quality were then estimated from the proportion of each sward type in the plot (i.e. number of times that sward type i was encountered in the plot/total number of sample points in the plot) and the herbage biomass and quality of each sward type. The Shannon index was used to calculate the evenness of the distribution of highly grazed patches (in line with Ménard et al., 2002 , VS and VI patches $\leq 8 \mathrm{~cm}$ were combined), tall vegetative patches (VT) and reproductive/dead patches (Repro/Dead) at plot scale.

\subsection{Animal measurements}

Dietary choices were measured by scan sampling at 5-min intervals of the activity of three animals within each group, with one 24-h observation per plot (i.e. three per treatment) and per period. Horses were identified by a number painted on both sides. A horse was considered to be grazing when it was biting, chewing or swallowing grass, or when it was walking with its muzzle close to the sward. For each individual recorded as grazing, the observer moved as close to the animal as possible without disturbing it in order to record one selected bite. Observers decided beforehand which bite to record once they were close enough to the animal (i.e. the fifth one) in order to avoid bias due to picking bites that were most clearly visible. This required animals to be trained for a week before measurements so that they would readily accept close proximity of the observer during grazing.

Bite types were recorded according to sward height type, i.e. vegetative short (VS, $\leq 4 \mathrm{~cm}$ ), vegetative intermediate (VI, $5-8 \mathrm{~cm}$ ), vegetative tall (VT, $\geq 9 \mathrm{~cm}$ ), reproductive/dead. A lamp was used for nighttime observations but the procedure was the same. Daytime observations also recorded dominant botanical family (grass, legumes or forbs) and whether the bite was pure (one botanical family only) or mixed. Ingestive behaviour measurements (bite rate and step rate during $1 \mathrm{~min}$ of uninterrupted grazing) were taken between scans throughout the $24 \mathrm{~h}$ to obtain further information on selective behaviour. A step was defined as a movement of one front leg. Four to eight recordings a day per sward type (i.e. VS, VI, VT, Repro/Dead) were targeted for each 
individual. Recordings were interrupted if the animal took at least three consecutive steps with its head up, stood head up without chewing grass for more than $3 \mathrm{~s}$, or started grazing another vegetation type. Mean bite rate and mean step rate were then estimated at plot level from the measurements on each sward type and the proportion of time spent grazing it. Mean bite rate-tomean step rate ratio informs on animal selectivity; the lower this ratio, the more selective the animal (Lazo and Soriguer, 1993).

Moreover, diet selection, defined as the proportion of a sward (bite) type in the diet relative to its proportion in the plot, was quantified by calculating selectivity indices $\left(S_{\mathrm{i}}\right)$ for each sward type using Jacobs' (1974) modification of Ivlev's electivity index:

$S_{i}=\left(c_{i}-a_{i}\right) /\left(c_{i}+a_{i}-2 c_{i} a_{i}\right)$,

where $c_{i}$ is proportion (between 0 and 1 ) of component $i$ in the diet and $a_{i}$ is proportion (between 0 and 1 ) of component $i$ in the plot. For each bite type $\left(c_{i}\right)$, data for individual animals were first aggregated per day and per plot and then linked to the relative abundance of this bite type in the plot. Si varies from -1 (never used) to +1 (exclusively used), with negative and positive values indicating avoidance and preference, respectively, and 0 indicating that a sward component is used in proportion to its availability. Jacobs' index was chosen for its low sensitivity to variations in the relative abundance of plant components, thus making it possible to rank both abundant and rare plant components according to their acceptability to the animals.

Diet digestibility (\%DM) was estimated from faecal CP content (\%DM) according to the equation of Mésochina et al. (1998):

Diet digestibility $=73.4-(178.72 /$ faecal CP content $)$.

The conditions of application of this equation were for herbage $\mathrm{CP}$ content higher than $7 \mathrm{~g} / \mathrm{kg}$ DM, which limits nitrogen recycling by horses (Mésochina et al., 1998); this was always the case in the present experiment. Faecal nitrogen has been used to estimate diet digestibility in a large number of horse studies (e.g. Edouard et al., 2009, 2010; Fleurance et al., 2010) as well as in other herbivores species (e.g. zebra: Barnier et al., 2014; sheep \& goats: Boval et al., 2003; cattle: Lukas et al., 2005). Five samples of fresh faeces from each of the three identified horses per plot were collected on the ground immediately after their emission throughout the $24 \mathrm{~h}$ behavioural observations. Samples were then mixed by individual and dried at $80^{\circ} \mathrm{C}$ to constant weight. Nitrogen was determined by the Kjeldahl method.

Liveweight gain data were obtained by weighing the three individuals observed in each plot each time the animals were turned in and turned out from pastures (mid-April, end of July, early September, early November).

\subsection{Biodiversity measurements}

Botanical diversity, i.e. percentage cover of all plant species in each plot, was estimated in June 2006 and 2009 in 25 quadrats $(50 \mathrm{~cm} \times 50 \mathrm{~cm})$ randomly placed along the parallel transects that were used for sward height measurements. Plant identification followed Tutin et al. (1964-1980) and, for Festuca species, Kerguélen and Plonka (1989). Shannon index was used to calculate the evenness of plant species distribution at the plot scale. Plant species were split into grasses, legumes and forbs, and were also classified according to the C-S-R model of primary strategies proposed by Grime et al. (1988).

Ground-dwellling arthropods were sampled for one month (June) by pitfall trapping from 2006 to 2009. Eighteen traps were placed in each paddock: 6 traps in vegetative short or intermediate patches (VS-VI), 6 in vegetative tall patches (VT), and 6 in reproductive patches (Repro). Each trap was filled with a mixture of $70 \%$ alcohol and 30\% water. Traps were $10 \mathrm{~cm}$ in diameter, and protected against horse trampling by a cage-like construction. Carabidae were counted and identified at species level while adults of other arthropod groups were counted and identified at higher taxonomic levels. Abundance of the different groups was calculated from the number of individuals captured per sward type, and from the proportion of each sward type in the plot. Adult grasshoppers were counted at the end of July 2006-2009, along three permanent transects $(50 \mathrm{~m} \times 2 \mathrm{~m})$ in each plot, and identified at species level from either visual observations or acoustic signature.

\subsection{Statistical analyses}

Data were analyzed using the SAS PROC Mixed procedure (version 9.2; SAS Institute Inc., Cary, NC, USA) for repeated measurements (Littell et al., 1998).

Herbage structure, biomass, quality, foraging behaviour, Jacobs' indices, and dry matter digestibility were analyzed, after arcsine transformation for proportions, in a model including main effects of stocking rate, year and season, and stocking rate $\times$ year, stocking rate $\times$ season, year $\times$ season, stocking rate $\times$ year $\times$ season interactions. Plot was used as statistical unit. Block was considered as a random effect, which generates a more powerful analysis by ensuring that variance due to block is taken into account and not just included in the error term. Differences between treatments were investigated using the Tukey correction for multiple comparisons. Significance of selection for $(\mathrm{Si}>0)$ or against $(\mathrm{Si}<0)$ each vegetation item was determined by comparing Jacobs' indices to zero using a Student's t-test.

As horses were removed from their pastures from the end of July to early September, livestock performance was analyzed separately from April to July and from September to November. The model included the main effects of stocking rate and year and stocking rate $\times$ year interaction. Livestock performance measured when animals were removed from their experimental plots was taken as a covariate when analyzing the influence of stocking rate between September and November. Block was considered as a random effect.

The influence of stocking rate on abundance and number of plant species recorded in 2009 was tested with 2006 data taken as a covariate. Insect abundance and diversity data were analyzed in a model including the main effects of stocking rate and year and stocking rate $\times$ year interaction. Abundance data for ground beetles and grasshoppers were further analyzed according to habitat affinity, i.e. short or tall grassland (Bellmann and Luquet, 1995; Coulon et al., 2000; Jeannel, 1941, 1942). Plot was used as statistical unit and block was considered as a random effect.

\section{Results}

\subsection{Herbage structure, biomass and quality}

Mean sward surface height (SSH) decreased from the beginning $(15.5 \pm 0.5 \mathrm{~cm} \mathrm{s.e.)}$ to the end of the grazing season $(10.7 \pm 0.7 \mathrm{~cm} \mathrm{~s}$. e.) in highly-grazed plots but peaked in summer $(30.6 \pm 2.1 \mathrm{~cm}$ s.e.) in moderately grazed plots, resulting in a significant stocking rate $\times$ season interaction $(\mathrm{p}<0.0001$; Table 1$)$. Mean $\mathrm{SSH}$ was higher at moderate stocking rate whatever the season $(\mathrm{p}<0.01)$. Sward height CV did not significantly differ between treatments and was higher during summer and autumn $(\mathrm{p}<0.0001$; Table 1$)$.

Higher abundance of VS and VI patches was found at the high stocking rate, with the highest values recorded during autumn for both stocking rate treatments (Table 1). Conversely, VT patches were more abundant at the moderate stocking rate and values were the highest in spring and the lowest in summer for both 
Table 1

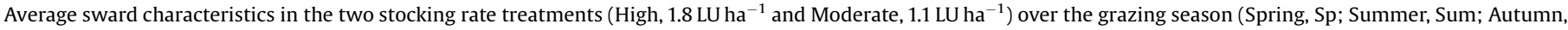
Aut) (mean \pm s.e.).

\begin{tabular}{|c|c|c|c|c|c|c|c|c|}
\hline & \multicolumn{2}{|c|}{ Stocking rate (SR) } & \multirow[b]{2}{*}{$\mathrm{p}$} & \multicolumn{3}{|c|}{ Season (S) } & \multirow[b]{2}{*}{$\mathrm{p}$} & \multirow{2}{*}{$\begin{array}{l}\mathrm{SR} \times \mathrm{S} \\
\mathrm{p}\end{array}$} \\
\hline & $\mathrm{H}$ & $\mathrm{M}$ & & $\mathrm{Sp}$ & Sum & Aut & & \\
\hline \multirow[t]{2}{*}{ Mean $\mathrm{SSH}^{1}(\mathrm{~cm})$} & 13.2 & 23.2 & & 18.7 & 22 & 13.9 & & ${ }^{* * *}$ \\
\hline & \pm 0.7 & \pm 1.6 & & \pm 1.4 & \pm 2.5 & \pm 1.1 & & \\
\hline \multirow[t]{2}{*}{$\mathrm{CV} \mathrm{SSH}^{2}(\%)$} & 65.8 & 60.7 & ns & $48.7^{\mathrm{b}}$ & $71.8^{\mathrm{a}}$ & $69.2^{\mathrm{a}}$ & $* * *$ & ns \\
\hline & \pm 2.4 & \pm 2.6 & & \pm 1.5 & \pm 9.3 & \pm 2.0 & & \\
\hline \multirow[t]{2}{*}{$\% \mathrm{VS}^{3}$} & 14.2 & 4.8 & ${ }^{* * *}$ & $2.9^{\mathrm{c}}$ & $10.3^{\mathrm{b}}$ & $15.3^{\mathrm{a}}$ & $* * *$ & ns \\
\hline & \pm 1.9 & \pm 0.7 & & \pm 0.6 & \pm 2.0 & \pm 2.1 & & \\
\hline \multirow[t]{2}{*}{$\% \mathrm{VI}^{3}$} & 22.2 & 10.1 & ${ }^{* * *}$ & $12.8^{\mathrm{b}}$ & $15.0^{\mathrm{b}}$ & $20.6^{\mathrm{a}}$ & $* * *$ & ns \\
\hline & \pm 1.6 & \pm 1.1 & & \pm 2.3 & \pm 2.2 & \pm 1.9 & & \\
\hline \multirow[t]{2}{*}{$\% \mathrm{VT}^{3}$} & 54.9 & 66.3 & ${ }^{* *}$ & $74.2^{\mathrm{a}}$ & $48.1^{\mathrm{c}}$ & $59.5^{\mathrm{b}}$ & $* * *$ & ns \\
\hline & \pm 3.2 & \pm 3.1 & & \pm 3.2 & \pm 2.8 & \pm 3.7 & & \\
\hline \multirow[t]{2}{*}{$\% \mathrm{R} / \mathrm{D}^{3}$} & 8.7 & 18.8 & & 10.1 & 26.6 & 4.5 & & ${ }^{* *}$ \\
\hline & \pm 1.7 & \pm 3.4 & & \pm 2.7 & \pm 3.9 & \pm 0.5 & & \\
\hline \multirow[t]{2}{*}{ Evenness $^{4}$} & 0.914 & 0.756 & ${ }^{* *}$ & $0.690^{\mathrm{b}}$ & $0.917^{\mathrm{a}}$ & $0.898^{\mathrm{a}}$ & ${ }^{* * *}$ & ns \\
\hline & \pm 0.031 & \pm 0.041 & & \pm 0.063 & \pm 0.024 & \pm 0.030 & & \\
\hline \multirow[t]{2}{*}{ Biomass (gDM m ${ }^{-2}$ ) } & 131.4 & 188.4 & ${ }^{* * *}$ & $171.3^{\mathrm{a}}$ & $175.9^{\mathrm{a}}$ & $132.5^{\mathrm{b}}$ & ${ }^{* *}$ & ns \\
\hline & \pm 6.4 & \pm 9.3 & & \pm 9.2 & \pm 15.3 & \pm 7.2 & & \\
\hline \multirow[t]{2}{*}{$\mathrm{CP}^{5}(\% \mathrm{DM})$} & 13.3 & 12.2 & ${ }^{* *}$ & $13.4^{\mathrm{a}}$ & $11.6^{\mathrm{b}}$ & $13.3^{\mathrm{a}}$ & $* * *$ & ns \\
\hline & \pm 0.3 & \pm 0.4 & & \pm 0.3 & \pm 0.4 & \pm 0.4 & & \\
\hline \multirow[t]{2}{*}{$\mathrm{NDF}^{6}$ (\%DM) } & 56.1 & 57.8 & $\dagger$ & $51.1^{\mathrm{b}}$ & $60.1^{a}$ & $59.7^{\mathrm{a}}$ & ${ }^{* * *}$ & ns \\
\hline & \pm 1.1 & \pm 1.1 & & \pm 1.0 & \pm 1.0 & \pm 0.7 & & \\
\hline
\end{tabular}

$\mathrm{a}, \mathrm{b}, \mathrm{c}$ Same-line values with different superscripts are significantly different at $\mathrm{p}<0.05$.

${ }^{\dagger} \mathrm{p}<0.1,{ }^{*} \mathrm{p}<0.05,{ }^{* *} \mathrm{p}<0.01,{ }^{* * *} \mathrm{p}<0.001$.

1 Sward surface height (SSH).

2 coefficient of variation (CV).

3 Vegetative Short (VS, $\leq 4 \mathrm{~cm}$ ), Vegetative Intermediate (VI, $5-8 \mathrm{~cm}$ ), Vegetative Tall $(\mathrm{VT},>9 \mathrm{~cm})$, Reproductive and Dead sward (R/D).

${ }^{4}$ evenness of the distribution of highly grazed patches (VS + VI), vegetative tall patches (VT) and reproductive/dead patches (R/D) at plot level.

5 crude protein $(\mathrm{CP})$.

${ }^{6}$ neutral detergent fiber (NDF), dry matter (DM).

treatments (Table 1 ). Abundance of R/D patches was the highest at the moderate stocking rate during summer $(39.2 \pm 2.8 \%$ s.e $v s$. $14.0 \pm 4.0 \%$ s.e. in highly grazed plots) (stocking rate $\times$ season, $\mathrm{p}<0.001$; Table 1 ); lower values were found in spring and autumn for both treatments $(p<0.01)$. Evenness of the distribution of highly-grazed patches (VS + VI), VT patches and R/D patches at plot scale was higher at high stocking rate than moderate stocking rate and higher in summer and autumn than in spring, but without any significant stocking rate $\mathrm{x}$ season interaction (Table 1 ).
Total herbage biomass was higher at the moderate stocking rate, with the lowest values found in autumn for both stocking rates (Table 1 ). Conversely, herbage quality was higher in highly grazed plots (Table 1). Herbage CP content was the lowest in summer whereas NDF content was higher during summer and autumn (Table 1). At both stocking rates, herbage biomass increased with patch-type height (VS: $46.0 \pm 2.9$, VI: $89.8 \pm 3.8$, VT: $174.6 \pm 5.1, \mathrm{R} / \mathrm{D}: 226.5 \pm 8.0 \mathrm{gDM} \mathrm{m}^{-2}$ s.e. on average), but the difference between VT and R/D patches was only significant for

Table 2

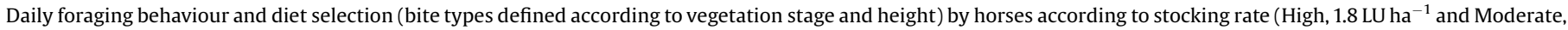
$1.1 \mathrm{LU} \mathrm{ha}^{-1}$ ) and season (mean \pm s.e.).

\begin{tabular}{|c|c|c|c|c|c|c|c|c|}
\hline & \multicolumn{3}{|c|}{ Stocking Rate (SR) } & \multicolumn{3}{|c|}{ Season $(S)$} & \multirow[b]{2}{*}{$\mathrm{p}$} & \multirow{2}{*}{$\begin{array}{l}\mathrm{SR} \times \mathrm{S} \\
\mathrm{p}\end{array}$} \\
\hline & $\mathrm{H}$ & $\mathrm{M}$ & $\mathrm{p}$ & spring & summer & autumn & & \\
\hline \multicolumn{9}{|l|}{ Foraging behaviour } \\
\hline \multirow[t]{2}{*}{$\mathrm{GT}^{1}(\min )$} & 793 & 780 & ns & $725^{c}$ & $796^{\mathrm{b}}$ & $838^{a}$ & ${ }^{* * *}$ & ns \\
\hline & \pm 17 & \pm 19 & & \pm 12 & \pm 24 & \pm 20 & & \\
\hline \multirow[t]{2}{*}{${ }^{2} \mathrm{~B} / \mathrm{S}$} & 9.2 & 7.8 & ${ }^{*}$ & $7.6^{\mathrm{b}}$ & $8.7^{\mathrm{a}}$ & $9.2^{\mathrm{a}}$ & ${ }^{*}$ & ns \\
\hline & \pm 0.4 & \pm 0.4 & & \pm 0.5 & \pm 0.6 & \pm 0.4 & & \\
\hline \multirow[t]{2}{*}{ Diet digestibility (\%DM) } & 59.4 & 58.6 & ns & $61.1^{\mathrm{a}}$ & $57.7^{\mathrm{c}}$ & $58.9^{\mathrm{b}}$ & ${ }^{* *}$ & ns \\
\hline & \pm 0.4 & \pm 0.5 & & \pm 0.4 & \pm 0.5 & \pm 0.5 & & \\
\hline \multicolumn{9}{|l|}{ Jacobs' indices } \\
\hline \multirow[t]{2}{*}{$\mathrm{VS}^{3}$} & +0.01 & +0.26 & ${ }^{* *}$ & $-0.15^{\mathrm{b}}$ & $+0.38^{a}$ & $+0.18^{a}$ & ${ }^{* * *}$ & ns \\
\hline & \pm 0.07 & $\pm \mathbf{0 . 0 7}$ & & \pm 0.11 & $\pm \mathbf{0 . 0 7}$ & $\pm \mathbf{0 . 0 6}$ & & \\
\hline \multirow[t]{2}{*}{$\mathrm{VI}^{3}$} & +0.16 & +0.39 & ${ }^{* * *}$ & $+0.19^{b}$ & $+0.36^{a}$ & $+0.27^{\mathrm{a}, \mathrm{b}}$ & ${ }^{*}$ & ns \\
\hline & $\pm \mathbf{0 . 0 5}$ & $\pm \mathbf{0 . 0 4}$ & & $\pm \mathbf{0 . 0 8}$ & $\pm \mathbf{0 . 0 5}$ & $\pm \mathbf{0 . 0 5}$ & & \\
\hline \multirow[t]{2}{*}{$\mathrm{VT}^{3}$} & -0.11 & $-0.09^{\dagger}$ & ns & $+0.03^{\mathrm{a}}$ & $-0.08^{a}$ & $-0.25^{\mathrm{b}}$ & ${ }^{* *}$ & ns \\
\hline & \pm 0.05 & \pm 0.05 & & \pm 0.06 & \pm 0.06 & \pm 0.04 & & \\
\hline \multirow[t]{2}{*}{ Repro/Dead ${ }^{3}$} & -0.35 & -0.52 & $\dagger$ & $-0.27^{\mathrm{a}}$ & $-0.35^{\mathrm{a}}$ & $-0.67^{b}$ & ${ }^{* *}$ & ns \\
\hline & \pm 0.08 & \pm 0.07 & & \pm 0.12 & \pm 0.07 & \pm 0.05 & & \\
\hline
\end{tabular}

${ }^{\mathrm{a}, \mathrm{b}}$ Same-line values within line with different superscripts are significantly different at $\mathrm{p}<0.05$.

Bold characters indicate items selected for and italics indicate items avoided at $\mathrm{p}<0.05$.

${ }^{\dagger} \mathrm{p}<0.1,{ }^{*} \mathrm{p}<0.05,{ }^{* *} \mathrm{p}<0.01,{ }^{* * *} \mathrm{p}<0.001$.

1 GT: grazing time per day.

2 B/S: bite per step.

3 Vegetative Short (VS, $\leq 4 \mathrm{~cm}$ ), Vegetative Intermediate (VI, 5-8 cm), Vegetative Tall (VT, $\geq 9 \mathrm{~cm}$ ), Reproductive and Dead sward (Repro/Dead). 
summer season (VT: $176.6 \pm 10.3$ vs. R/D: $243.1 \pm 16.0 \mathrm{gDM} \mathrm{m}^{-2} \mathrm{~s}$ e.; sward type $\times$ season, $\mathrm{p}<0.01)$. Patch $\mathrm{CP}$ content decreased as sward height increased (VS: $14.5 \pm 0.3, \mathrm{VI}: 13.6 \pm 0.3$, VT: $12.6 \pm 0.2, \mathrm{R} / \mathrm{D}: 11.6 \pm 0.3 \% \mathrm{DM}$ s.e. on average $)(\mathrm{p}<0.001)$; in highly grazed plots, there were no significant differences between $\mathrm{CP}$ content of short $(14.4 \pm 0.4 \%$ s.e. $)$ and intermediate patches ( $14.1 \pm 0.4 \%$ s.e.). Herbage NDF content was higher in VT and R/D patches $(58.1 \pm 0.6 \%$ s.e. on average) than in shorter patches $(55.3 \pm 0.5 \%$ s.e. $)(\mathrm{p}<0.01)$.

\subsection{Foraging behaviour and animal performance}

Horse daily grazing time did not differ between stocking rates and increased along the grazing season (Table 2). Horses spent a large part of their feeding time on VT patches, especially at the moderate stocking rate. The use of these patches was highest in spring at both stocking rates (proportion in the diet: $0.815 \pm 0.025$ vs. $0.719 \pm 0.020$ s.e. at the moderate and high stocking rate, respectively, $\mathrm{p}<0.001$ ) but at the moderate stocking rate it was lowest in summer $(0.481 \pm 0.028$ s.e $)$ whereas at the high stocking rate it was lower in summer and autumn ( $0.382 \pm 0.022$ s.e.) (stocking rate $\times$ season, $\mathrm{p}<0.01$ ). Horses made very little use of $\mathrm{R} /$ D patches $(0.081 \pm 0.002$ and $0.050 \pm 0.010$ s.e. at the moderate and high stocking rate, $\mathrm{p}<0.05)$ with the highest values found in summer for both treatments $(0.132 \pm 0.020$ s.e $)(\mathrm{p}<0.01)$.

Horses strongly selected VI patches with an even more pronounced selection at the moderate stocking rate $(\mathrm{p}<0.001)$ and during summer $(\mathrm{p}<0.05)$ (Table 2$)$. Horses grazed at moderate stocking rate also selected for VS patches in summer and autumn (Table 2). Analysis of bite botanical composition revealed that horses selected VI and VS patches when they were dominated by grasses (SIG) or legumes (L, mainly clover; Fig. 1) whereas patches dominated by forbs (SIF) were avoided at the high stocking rate and used proportionally to their availability at the moderate stocking rate (Fig. 1). VT patches were avoided in autumn at both stocking rates, $(\mathrm{p}<0.01$; Table 2 ). This was mainly due to a strong rejection of tall forbs (TF) by horses while tall grass patches (TPG) were
Table 3

Mean percentage cover of dominant plant species at plot scale in 2009 after four years of contrasted stocking rates (High, $1.8 \mathrm{LU} \mathrm{ha}^{-1}$ vs. Moderate, $1.1 \mathrm{LU} \mathrm{ha}^{-1}$ ).

\begin{tabular}{lrlr}
\hline High stocking rate & \multicolumn{3}{c}{ Moderate stocking rate } \\
\hline Poa trivialis & 18.5 & Dactylis glomerata & 16.6 \\
Trifolium repens & 15.2 & Poa trivialis & 15.6 \\
Agrostis tenuis & 10.8 & Holcus lanatus & 11.9 \\
Holcus lanatus & 9.1 & Ranunculus repens & 8.6 \\
Taraxacum officinalis & 7.2 & Trifolium repens & 6.0 \\
Ranunculus repens & 6.7 & Festuca arundinacea & 4.8 \\
Dactylis glomerata & 6.6 & Agrostis tenuis & 3.7 \\
Lolium perenne & 4.5 & Plantago lanceolata & 3.4 \\
Stellaria graminaea & 4.0 & Lolium perenne & 3.3 \\
Poa pratensis & 2.7 & Poa pratensis & 3.0 \\
\hline
\end{tabular}

selected (Fig. 1). Overall, horses avoided forbs (F, Fig. 1) and R/D patches (Table 2).

The lower bite-to-step ratio $(\mathrm{p}<0.05$, Table 2$)$ found at moderate compared to high stocking rate confirmed that horses grazed more selectively as grazing intensity decreased. Horse selectivity also decreased along the grazing season (Table 2 ). Reduction in grazing intensity did not significantly affect the diet digestibility (Table 2), which was highest in spring, lowest in summer and intermediate in autumn (Table 2).

Average horse daily liveweight gain was significantly higher at moderate stocking rate than high stocking rate between April and the end of July $\left(441 \pm 45 \mathrm{~g}\right.$ animal ${ }^{-1} \mathrm{~d}^{-1}$ vs. $317 \pm 43 \mathrm{~g}_{\text {animal }}{ }^{-1}$ $\mathrm{d}^{-1}$ s.e. at the high stocking rate; stocking rate, $\left.\mathrm{p}<0.05\right)$ but was not significantly different between treatments during autumn ( $343 \pm 65 \mathrm{~g}_{\text {animal }}{ }^{-1} \mathrm{~d}^{-1}$ and $271 \pm 62 \mathrm{~g}_{\text {animal }}{ }^{-1} \mathrm{~d}^{-1}$ s.e. at the moderate and high stocking rate, respectively; stocking rate, $\mathrm{p}=0.378$ ).

\subsection{Plant diversity}

The abundance of dominant plant species after four years of contrasted stocking rates is reported in Table 3. There was not stocking rate effect on plant species richness or evenness of their

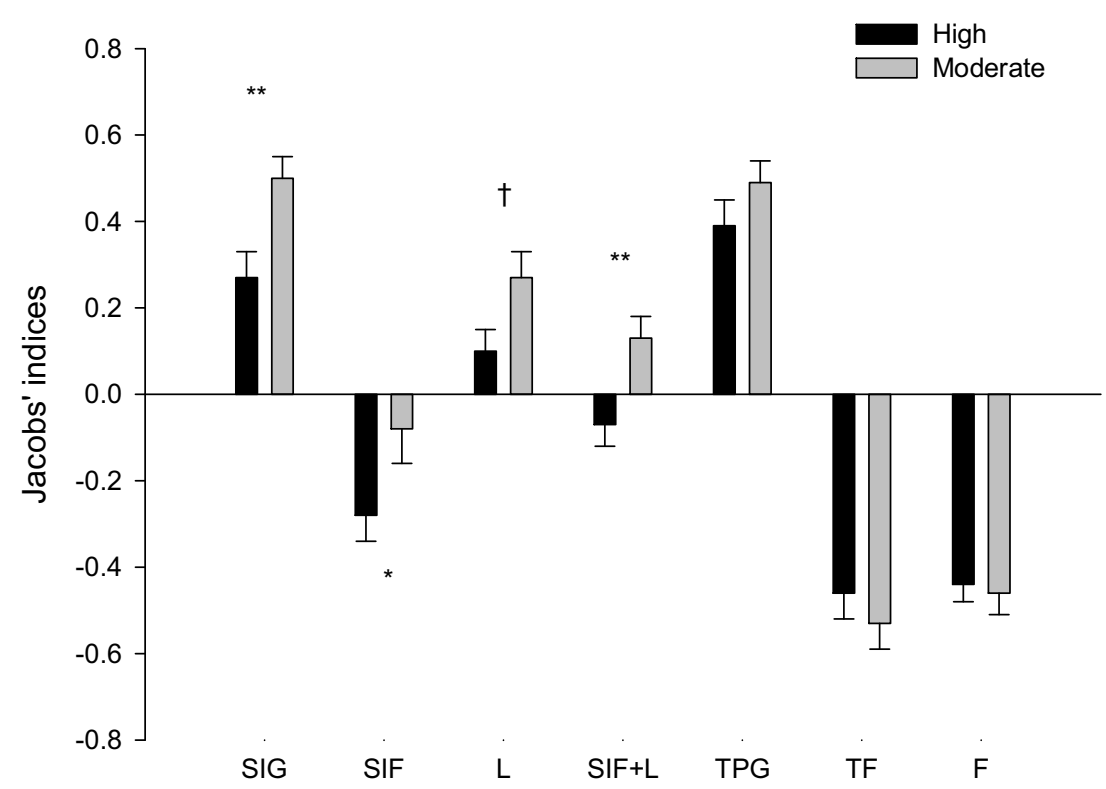

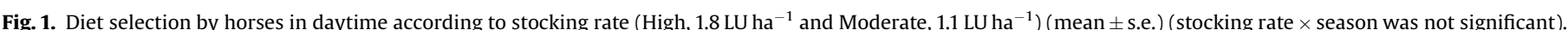

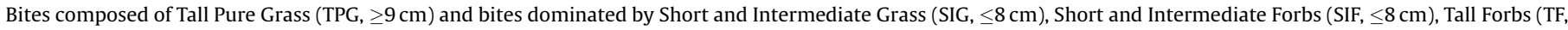

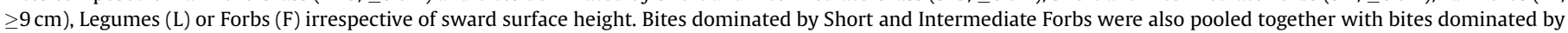
Legumes in a synthetic bite type SIF $+\mathrm{L}$.

${ }^{\dagger} \mathrm{p}<0.1,{ }^{*} \mathrm{p}<0.05,{ }^{* *} \mathrm{p}<0.01$

Jacobs' indices were significantly different from zero (Student's $t$-test, $\mathrm{p}<0.05$ ) apart for SIF at Moderate stocking rate and for SIF $+\mathrm{L}$ at High stocking rate. 
Table 4

Plant species richness (mean \pm s.e.), evenness of plant species distribution, and abundance of functional types after four years of contrasted stocking rates (High 1.8 $\mathrm{LU} \mathrm{ha}^{-1}$ vs. Moderate, $\left.1.1 \mathrm{LU} \mathrm{ha}^{-1}\right){ }^{1}$

\begin{tabular}{llll}
\hline & \multicolumn{2}{l}{ Stocking rate } & \\
\cline { 2 - 3 } & High & Moderate & $\mathrm{p}$ \\
\hline Species richness & 27.3 & 28.3 & $\mathrm{~ns}$ \\
Evenness & \pm 0.3 & \pm 2.9 & \\
& 0.749 & 0.782 & $\mathrm{~ns}$ \\
\% Grasses & \pm 0.019 & \pm 0.021 & \\
\% Legumes & 55.3 & 68.7 & $\mathrm{~ns}$ \\
& \pm 6.1 & \pm 1.2 & \\
Incl. competitive types (C-S-R and C) & 2 & 15.2 & $\mathrm{~ns}$ \\
& 15.7 & 6.8 & $*$ \\
\% Forbs & \pm 1.9 & \pm 1.9 & \\
& 15.2 & \pm 1.2 & $\mathrm{~ns}$ \\
Incl. ruderal types (R and C-R ${ }^{2}$ & 29.3 & 24.3 & \\
& \pm 4.8 & \pm 1.3 & \\
& 15.2 & 13.3 & \\
& \pm 1.2 & \pm 3.1 &
\end{tabular}

${ }^{\dagger} \mathrm{p}<0.1,{ }^{*} \mathrm{p}<0.05,{ }^{* *} \mathrm{p}<0.01,{ }^{* * *} \mathrm{p}<0.001$.

1 For each variable, data registered in 2006 was considered as a covariate in the model.

${ }^{2}$ In the model by Grime et al. (1988), competitive perennial species (C-S-R and C types) are characterized by a rapid leaf turnover. Ruderal species (the annual $R$ type and the most competitive C-R type) are fast-growing and capable of colonizing gaps resulting from trampling and summer drought.

distribution at plot scale (Table 4). Competitive Trifolium repens was 2.5 -fold more abundant after four years at the higher stocking rate $(\mathrm{p}<0.05)$. Ruderal forb species that can colonize gaps (among which Taraxacum officinalis) tended to be more abundant in highly grazed plots $(p=0.085$, Tables 3 and 4$)$. We found no significant differences for abundance of overall grasses or grass species classified according to Grime et al. (1988) (Table 4).

\subsection{Insect diversity}

Insect abundance and species richness were highly variable between experimental years due to fluctuating climatic conditions, especially precipitations (Tables 5, 6 and 7). Total number of ground-dwelling arthropods per plot (626 individuals per year on average) was unaffected by stocking rate (Table 5 ). However, Diplopoda $(\mathrm{p}<0.05)$ and among the Coleoptera, Elateridae $(\mathrm{p}<0.01)$ and Carabidae $(\mathrm{p}=0.06)$ were more abundant at moderate stocking rate whereas Curculionidae were more abundant at high stocking rate $(\mathrm{p}<0.05)$ (Table 5$)$. Stocking rate did not significantly affect Carabidae species richness (22 species per plot and per year on average; Table 6 ). However, a reduction of stocking rate benefited Carabidae from tall grasslands (including Ophonus rufipes and Poecilus versicolor), which significantly increased abundance $(\mathrm{p}<0.05$, Table 6$)$. For grasshoppers, neither species richness ( 8 species per plot and per year) nor abundance (95 individuals) was significantly affected by stocking rate (Table 7). However, grasshoppers from tall grasslands (including Chortippus parallelus, Chortippus albomarginatus, Stethophyma grossum, Conocephalus fuscus, Metrioptera roeselli) were more abundant in plots grazed at a moderate stocking rate $(\mathrm{p}<0.05$, Table 7).

\section{Discussion}

Horses exhibited a typical patch grazing pattern (Adler et al., 2001 ), selectively grazing highly-nutritive patches below $8 \mathrm{~cm}$ in summer and autumn. They avoided tall vegetative patches during autumn and reproductive/dead patches along the whole grazing season. Edouard et al. (2010) showed that digestible protein is the
Table 5

Overall abundance of ground-dwelling arthropods $(\log (\mathrm{N}+1)$ individuals per plot) and abundance of selected groups under the two stocking rate treatments (High 1.8 $\mathrm{LU} \mathrm{ha}^{-1}$ and Moderate, $1.1 \mathrm{LU} \mathrm{ha}^{-1}$ ).

\begin{tabular}{|c|c|c|c|c|c|}
\hline & \multicolumn{2}{|c|}{ Stocking rate (SR) } & \multirow[b]{2}{*}{$\mathrm{p}$} & \multirow{2}{*}{$\begin{array}{l}\text { Year (Y) } \\
\mathrm{p}\end{array}$} & \multirow{2}{*}{$\begin{array}{l}\mathrm{SR} \times \mathrm{Y} \\
\mathrm{p}\end{array}$} \\
\hline & High & Moderate & & & \\
\hline TOTAL & $\begin{array}{l}2.74 \\
\pm 0.07\end{array}$ & $\begin{array}{l}2.76 \\
\pm 0.06\end{array}$ & ns & ${ }^{* * * *}$ & ns \\
\hline Aranaeae & $\begin{array}{l}2.29 \\
\pm 0.09\end{array}$ & $\begin{array}{l}2.32 \\
\pm 0.11\end{array}$ & ns & ${ }^{* * *}$ & ns \\
\hline \multicolumn{6}{|l|}{ Coleoptera } \\
\hline Carabidae & $\begin{array}{l}2.03 \\
\pm 0.06\end{array}$ & $\begin{array}{l}2.13 \\
\pm 0.05\end{array}$ & $\dagger$ & ${ }^{* *}$ & ns \\
\hline Chrysomelidae & $\begin{array}{l}0.62 \\
\pm 0.10\end{array}$ & $\begin{array}{l}0.53 \\
\pm 0.07\end{array}$ & ns & ns & ns \\
\hline Coccinellidae & $\begin{array}{l}0.45 \\
\pm 0.13\end{array}$ & $\begin{array}{l}0.46 \\
\pm 0.12\end{array}$ & ns & ${ }^{* * *}$ & ns \\
\hline Curculionidae & $\begin{array}{l}0.76 \\
\pm 0.07\end{array}$ & $\begin{array}{l}0.54 \\
\pm 0.06\end{array}$ & ${ }^{*}$ & $\dagger$ & ns \\
\hline Elateridae & $\begin{array}{l}0.83 \\
\pm 0.06\end{array}$ & $\begin{array}{l}1.00 \\
\pm 0.06\end{array}$ & ${ }^{* *}$ & ns & ns \\
\hline Staphylinidae & $\begin{array}{l}1.60 \\
\pm 0.10\end{array}$ & $\begin{array}{l}1.67 \\
\pm 0.06\end{array}$ & ns & ${ }^{* *}$ & ns \\
\hline Diplopoda & $\begin{array}{l}0.01 \\
\pm 0.01\end{array}$ & $\begin{array}{l}0.15 \\
\pm 0.07\end{array}$ & ${ }^{*}$ & ns & ns \\
\hline
\end{tabular}

${ }^{\dagger} \mathrm{p}<0.1,{ }^{*} \mathrm{p}<0.05,{ }^{* *} \mathrm{p}<0.01,{ }^{* * *} \mathrm{p}<0.001$.

Table 6

Species richness and abundance of Carabidae ( $\log \mathrm{N}$ individuals per plot) under the two stocking rate treatments (High, $1.8 \mathrm{LU} \mathrm{ha}^{-1}$ and Moderate, $1.1 \mathrm{LU} \mathrm{ha}^{-1}$ ).

\begin{tabular}{|c|c|c|c|c|c|}
\hline & \multicolumn{2}{|c|}{ Stocking rate (SR) } & \multirow[b]{2}{*}{$\mathrm{p}$} & \multirow{2}{*}{$\begin{array}{l}\text { Year }(\mathrm{Y}) \\
\mathrm{p}\end{array}$} & \multirow{2}{*}{$\begin{array}{l}\mathrm{SR} \times \mathrm{Y} \\
\mathrm{p}\end{array}$} \\
\hline & High & Moderate & & & \\
\hline Species richness & $\begin{array}{l}21.2 \\
\pm 1.6\end{array}$ & $\begin{array}{l}22.4 \\
\pm 1.6\end{array}$ & ns & **** & ns \\
\hline $\begin{array}{l}\text { Abundance }^{1} \\
\text { short grassland }\end{array}$ & $\begin{array}{l}0.84 \\
\pm 0.09\end{array}$ & $\begin{array}{l}0.81 \\
\pm 0.14\end{array}$ & ns & ${ }^{*}$ & ns \\
\hline tall grassland & $\begin{array}{l}1.72 \\
\pm 0.05\end{array}$ & $\begin{array}{l}1.83 \\
\pm 0.03\end{array}$ & ${ }^{*}$ & ns & ns \\
\hline generalists and undetermined & $\begin{array}{l}1.62 \\
\pm 0.10\end{array}$ & $\begin{array}{l}1.72 \\
\pm 0.08\end{array}$ & ns & ${ }^{* *}$ & ns \\
\hline
\end{tabular}

${ }^{\dagger} \mathrm{p}<0.1,{ }^{*} \mathrm{p}<0.05,{ }^{* *} \mathrm{p}<0.01,{ }^{* * *} \mathrm{p}<0.001$.

1 Abundance data were analyzed in relation to habitat affinity: i.e. short grassland $(<10 \mathrm{~cm})$ or tall grassland $(>10 \mathrm{~cm})$. Abundance of wide-ranging generalist ground beetles and species for which habitat affinity is undetermined represented $44.3 \%$ of the total number of individuals.

Table 7

Species richness and abundance of grasshoppers $(\log (\mathrm{N}+1)$ individuals per plot) under the two stocking rate treatments (High, $1.8 \mathrm{LUha}^{-1}$ and Moderate, $1.1 \mathrm{LUha}^{-1}$ ).

\begin{tabular}{|c|c|c|c|c|c|}
\hline & \multicolumn{2}{|c|}{ Stocking rate (SR) } & \multirow[b]{2}{*}{$\mathrm{p}$} & \multirow[t]{2}{*}{ Year $(Y)$} & \multirow{2}{*}{$\begin{array}{l}\mathrm{SR} \times \mathrm{Y} \\
\mathrm{p}\end{array}$} \\
\hline & High & Moderate & & & \\
\hline Species richness & $\begin{array}{l}7.7 \\
\pm 0.7\end{array}$ & $\begin{array}{l}8.6 \\
\pm 0.8\end{array}$ & ns & ${ }^{* * *}$ & ns \\
\hline Abundance $^{1}$ & $\begin{array}{l}1.75 \\
\pm 0.15\end{array}$ & $\begin{array}{l}1.79 \\
\pm 0.17\end{array}$ & ns & ${ }^{* * *}$ & ns \\
\hline short grassland & $\begin{array}{l}1.09 \\
\pm 0.15\end{array}$ & $\begin{array}{l}0.86 \\
\pm 0.16\end{array}$ & ns & ${ }^{* * *}$ & ns \\
\hline tall grassland & $\begin{array}{l}1.56 \\
\pm 0.19\end{array}$ & $\begin{array}{l}1.73 \\
\pm 0.17\end{array}$ & ${ }^{*}$ & ${ }^{* * *}$ & ns \\
\hline
\end{tabular}

${ }^{\dagger} \mathrm{p}<0.1,{ }^{*} \mathrm{p}<0.05,{ }^{* *} \mathrm{p}<0.01,{ }^{* * *} \mathrm{p}<0.001$.

1 Abundance data were analyzed in relation to habitat affinity: i.e. short grassland $(<10 \mathrm{~cm})$ or tall grassland $(>10 \mathrm{~cm})$. 
best predictor of horse grazing selection pattern. Our results are in line with this conclusion since crude protein content was the highest in short and intermediate patches. Horses selected grasses, which confirms previous observations in semi-natural grasslands (Cornelissen and Vulink, 2015; Duncan, 1983; Gordon, 1989) and, to a lesser extent, legumes. Horses avoided forbs, especially in tall patches, which could be explained by their inability to detoxify forb secondary metabolites (Duncan, 1992).

Horse selection for short and intermediate vegetative patches was even more pronounced in plots grazed at a moderate stocking rate where sward height and herbage biomass were higher. In these plots, horses also had a lower bite-to-step ratio that confirms they grazed more selectively. This allowed them to maintain diet digestibility at the same level as in highly grazed plots while average herbage quality was lower. Similarly, cattle decreased bite-to-step ratio as stocking rate decreased (Dumont et al., 2007a), which allowed them to maintain diet quality in semi-natural grasslands (Dumont et al., 2007a; Schlegel et al., 2000). In mesophile grasslands, selection for short patches by cattle was also more pronounced at a lenient stocking rate, which represents a key mechanism in the creation of pasture heterogeneity via the maintenance of leaves in an early phenological state and a reduction of senescent material (Dumont et al., 2007b).

At both stocking rates, horses increased their grazing time from 12 to $14 \mathrm{~h}$ over the grazing season, probably to compensate for lower herbage availability and digestibility (Arnold, 1984). Liveweight gains per animal matched horse growth recommendations in both treatments (INRA, 2015) and were significantly higher during spring and early summer in plots grazed at a moderate stocking rate than at a high stocking rate. As daily grazing time and diet digestibility did not differ between treatments, the higher performance by horses under moderate grazing intensity probably resulted from higher herbage biomass ( $+64 \mathrm{gDM} \mathrm{m}^{-2}$ on average in spring and summer). In autumn, the difference in herbage biomass was lower $\left(+43 \mathrm{gDM} \mathrm{m}^{-2}\right.$ at the moderate stocking rate) and maybe not enough to affect nutrient intake rate; liveweight gains per animal no longer differed between treatments.

The limited use of flowering plants by horses may benefit grassland diversity (Marion et al., 2010; Nolte et al., 2013; Stewart and Pullin, 2008) as well as the diversity of flower-visiting insects (Öckinger et al., 2006). Despite their more pronounced selection of short and intermediate vegetative patches at the moderate stocking rate, horses created and maintained a strong sward structural heterogeneity in both treatments. Hence, the coefficient of variation of sward surface height did not significantly differ between stocking rate treatments, and the evenness of patch distribution was even higher at the high stocking rate. In line with our hypothesis, decreasing stocking rate did not increase sward structural heterogeneity in horse-grazed pastures, which is also consistent with recent observations by Nolte et al. (2014) in grasslands of high nature value. Stability of short grazed patches within a mosaic of ungrazed tall vegetation patches has previously been evidenced in the same experimental plots with a stable pattern from the summer peak of biomass to the autumn, and also between two successive years at both stocking rates (Dumont et al., 2012). Patch stability was related to local abundance of legumes and forbs, which is consistent with our observations that horses selected legumes at both stocking rates and selected short and intermediate patches dominated by forbs and legumes under lenient grazing. Patch stability can favour functional diversity in pastures grazed by cattle at a low stocking rate (Bloor and Pottier, 2014; Dumont et al., 2011). Very few studies have analyzed the consequences of contrasted grazing management on vegetation diversity in horse-grazed pastures
(Nolte et al., 2013Magnusson and Magnusson, 1990; Nolte et al., 2013). Here, the two stocking rates resulted in divergent dynamics of legumes, which increased from 4 to $16 \%$ of plot area at the high stocking rate but remained constant at around $7 \%$ in taller swards grazed at the moderate stocking rate. Plant species richness was unaffected by stocking rate after 4 years. A similar conclusion was drawn in moist grasslands of the Poitevin Marsh (Mid-West France, close to the Atlantic coast), where 5 years of horse grazing under contrasting stocking rates (0.51.5LU ha ${ }^{-1}$ ) left plant species richness unchanged (Amiaud, 1998). These results should, however be confirmed in the longer term, as shifts in species richness are known to be slower than shifts in functional type abundance. In Iceland, Magnússon and Magnússon (1990) reported shifts in species abundance and species richness in horse-grazed pastures under contrasted stocking rates after 8 years. However, these shifts were driven by overgrazing at the highest stocking rate (average height $<5 \mathrm{~cm}, 7 \%$ of bare soil) resulting in the development of new species, mainly bryophytes.

Consistent with the lack of effect of stocking rate on sward heterogeneity, we did not record any benefit of decreasing grazing intensity on insect species richness. The higher abundance of Carabidae and grasshoppers from tall grasslands in moderatestocking-rate plots can be explained by a higher vegetation biomass. In the case of predatory Carabidae, it could also reflect increased abundance of prey in the tall vegetation of moderatelygrazed plots as well as a more favourable microclimate (Dennis et al., 1998, 2004; Tscharntke and Greiler, 1995). Horse faeces in tall grass areas (Loucougaray et al., 2004; Ödberg and FrancisSmith, 1977) may also have attracted dung beetles which, in turn, would attract their predators. For grasshoppers, our results are in line with numerous studies that demonstrate the benefit of lesser disturbance in plots grazed at a moderate stocking rate (Cherril and Brown, 1992; Dumont et al., 2009; Hutchinson and King, 1980; Kati et al., 2012; Kruess and Tscharntke, 2002; Marini et al., 2009; O'Neill et al., 2003; Tscharntke and Greiler, 1995; Wallis de Vries et al., 2007). Furthermore, the stability of tall patches in successive years (Dumont et al., 2012) could limit the risk of oviposition sites being destroyed, and provides forage and shelter for the next generations (Jerrentrup et al., 2014). At the patch scale, Holmquist et al. (2014) reported a lower diversity of arthropods in lawns that are repeatedly grazed by horses compared to ungrazed patches. Two more groups that benefited from a decrease in grazing intensity by horses were Elateridae, whose adults are phytophagous, and Diplopoda that rely on dead biomass (Hutchinson and King, 1980). A high stocking rate did however benefit Curculionidae that largely depend on clover (Dennis et al., 2004). No effects of grazing intensity were found on spider abundance, which confirms previous observations in seminatural grasslands (Dennis et al., 2001, 2008; Scohier and Dumont, 2012), though spider abundance sometimes declined in intensively-grazed pastures (Hutchinson and King, 1980).

This is the first study to simultaneously assess the influence of grazing management on horse foraging behaviour, horse performances and pasture biodiversity in mesophile grasslands. Horses were able to maintain performances in plots grazed at a lenient stocking rate by selectively grazing on short vegetative patches of high nutritive value. In line with our hypothesis, decreasing grazing intensity did not increase sward heterogeneity as the horses created stable vegetation patches in both treatments. Floristic and arthropod diversity remained unaffected by stocking rate over the course of this four-year study. Extensive management only increased the abundance of some insect taxa that rely on tall vegetation, and did not benefit all species from the local pool. Conversely, decreasing stocking rate will have a strong direct effect on number of horses per unit area that needs to be trade-off relative to its relatively weak benefits on biodiversity. Based on the 
evidence of this study, a more sustainable way of preserving floristic and arthropod diversity in horse farming systems would be to preserve a mosaic of grasslands under contrasted management regimes at farm level.

\section{Acknowledgements}

This study was performed with financial support from the IFCE. The authors thank the staff of the IFCE experimental farm Laurence Wimel, Patrice Dupuy, Claude Larry, Jean-Louis Larry, Jacques Boulanger - for their technical assistance; Nadège Edouard and Francis Decuq from INRA UMR1213 as well as the students Aurore Guiet, Sophie Steelandt, Alexia Mouchet, Laure Sallefranque and Marie Bourguet for help with field measurements. We are grateful to Benjamin Calmont and Emmanuel Boitier from the Societé d'Histoire Naturelle Alcide Orbigny for monitoring insect diversity.

\section{References}

Öckinger, E., Eriksson, A.K., Smith, H.G., 2006. Effects of grassland abandonment, restoration and management on butterflies and vascular plants. Biol. Conserv. 133, 291-300.

Ödberg, F.O., Francis-Smith, K., 1977. Studies on the formation of ungrazed eliminative areas in fields used by horses. Appl. Anim. Ethol. 3, 27-34.

Adler, P.B., Raff, D.A., Lauenroth, W.K., 2001. The effect of grazing on the spatial heterogeneity of vegetation. Oecologia 128, 465-479.

Amiaud, B., 1998. Dynamique végétale d'un écosystème prairial soumis à différentes modalités de pâturage, exemple des communaux du Marais Poitevin. PhD Thesis. Université de Rennes 1, Rennes, France.

Arnold, G.W., 1984. Comparison of the time budgets and circadian patterns of maintenance activities in sheep: cattle and horses grouped together. Appl. Anim. Behav. Sci. 13, 19-30.

Barnier, F., Valeix, M., Duncan, P., Chamaille-James, S., Barre, P., Loveridge, A.J., Macdonald, D.W., Fritz, H., 2014. Diet quality in a wild grazer declines under the threat of an ambush predator. P. Roy. Soc. B Biol. Sci. 281 (article number: 20140446).

Bellmann, H., Luquet, G.C., 1995. Guide des sauterelles, grillons et criquets d'Europe occidentale (Guide to grasshoppers, crickets and locusts in western Europe). Delachaux et Niestlé, Lausanne, Switzerland.

Bloor, J.M.G., Pottier, J., 2014. Grazing and spatial heterogeneity: implications for grassland structure and function. In: Mariotte, P., Kardol, P. (Eds.), Grassland Biodiversity and Conservation in a Changing World. Nova Science Publishers, pp. 135-162.

Boval, M., Archimede, H., Fleury, J., Xandé, A., 2003. The ability of faecal nitrogen to predict digestibility for goats and sheep fed with tropical herbage. J. Agric. Sci. $140,443-450$.

Catorci, A., Gatti, R., Cesaretti, S., 2012. Effect of sheep and horse grazing on species and functional composition of sub-Mediterranean grasslands. Appl. Veg. Sci.15, 459-469.

Cherril, A.J., Brown, V.K., 1992. Ontogenic changes in the micro-habitat preferences of Decticus verrucivorus (Orthoptera: Tettigonidae) at the edge of its range. Ecography 15, 37-44.

Cornelissen, P., Vulink, J.T., 2015. Density-dependent diet selection and body condition of cattle and horses in heterogeneous landscapes. Appl. Anim. Behav. Sci. 163, 28-38.

Coulon, J., Marchal, P., Pupier, R., Richoux, P., Allemand, R., Genest, L.-C., Clary, J., 2000. Coléoptères de Rhône-Alpes, Carabiques et Cicindèles. Muséum et Société linnéenne de Lyon.

Dennis, P., Young, M.R., Gordon, I.J., 1998. Distribution and abundance of small insects and arachnids in relation to structural heterogeneity of grazed indigenous grasslands. Ecol. Entomol. 23, 253-264.

Dennis, P., Young, M.R., Bentley, C., 2001. The effects of varied grazing management on epigeal spiders, harvestmen and pseudoscorpions of Nardus stricta grassland in upland Scotland. Agric. Ecosyst. Environ. 86, 39-57.

Dennis, P., Doering, J., Stockan, J.A., Jones, J.R., Rees, M.E., Vale, J.E., Sibbald, A.R., 2004. Consequences for biodiversity of reducing inputs to upland temperate pastures: effects on beetles (Coleoptera) of cessation of nitrogen fertilizer application and reductions in stocking rates of sheep. Grass Forage Sci. 59, 121 135.

Dennis, P., Skartveit, J., McCracken, D.I., Pakeman, R.J., Beaton, K., Kunaver, A., Evans, D.M., 2008. The effects of livestock grazing on foliar arthropods associated with bird diet in upland grasslands of Scotland. J. Appl. Ecol. 45, 279-287.

Dumont, B., Garel, J.P., Ginane, C., Decuq, F., Farruggia, A., Pradel, P., Rigolot, C., Petit M., 2007a. Effect of cattle grazing a species-rich mountain pasture under different stocking rates on the dynamics of diet selection and sward structure. Animal 1, 1042-1052.
Dumont, B., Rook, A.J., Coran Ch Röver, K.-U., 2007b. Effects of livestock breed and grazing intensity on biodiversity and production in grazing systems. 2. Diet selection. Grass Forage Sci. 62, 159-171.

Dumont, B., Farruggia, A., Garel, J.-P., Bachelard, P., Boitier, E., Frain, M., 2009. How does grazing intensity influence the diversity of plants and insects in a speciesrich upland grassland on basalt soils? Grass Forage Sci. 64, 92-105.

Dumont, B., Carrère, P., Ginane, C., Farruggia, A., Lanore, L., Tardif, A., Decuq, F., Darsonville, O., Louault, F., 2011. Plant-herbivore interactions affect the initia direction of community changes in an ecosystem manipulation experiment. Basic Appl. Ecol. 12, 187-194.

Dumont, B., Rossignol, N., Loucougaray, G., Carrère, P., Chadoeuf, J., Fleurance, G., Bonis, A., Farruggia, A., Gaucherand, S., Ginane, C., Louault, F., Marion, B. Mesléard, F., Yavercovski, N., 2012. When does grazing generate stable vegetation patterns in temperate pastures? Agric. Ecosyst. Environ. 153, 50-56.

Duncan, P., 1983. Determinants of the use of habitat by horses in a Mediterranean wetland. J. Anim. Ecol. 52, 93-109.

Duncan, P., 1992. Horses and Grasses: the Nutritional Ecology of Equids and Their Impact on the Camargue. Springer-Verlag, New-York.

Edouard, N., Fleurance, G., Dumont, B., Baumont, R., Duncan, P., 2009. Does sward height affect feeding patch choice and voluntary intake in horses? Appl. Anim. Behav. Sci. 119, 219-228.

Edouard, N., Duncan, P., Dumont, B., Baumont, R., Fleurance, G., 2010. Foraging in a heterogeneous environment-an experimental study of the trade-off between intake rate and diet quality. Appl. Anim. Behav. Sci. 126, 27-36.

Eschen, R., Brook, A.J., Maczey, N., Bradbury, A., Mayo, A., Watts, P., Buckingham, D., Wheeler, K., Peach, W.J., 2012. Effects of reduced grazing intensity on pasture vegetation and invertebrates. Agric. Ecosyst. Environ. 151, 53-60.

European Horse Network, 2010. The European Horse Industry in the European Regions. http://www.europeanhorsenetwork.eu/the-horse-industry (accessed 26.11.15.)..

Fleurance, G., Duncan, P., Fritz, H., Cabaret, J., Gordon, I.J., 2005. Importance of nutritional and anti-parasite strategies in the foraging decisions of horses: an experimental test. Oikos 110, 602-612.

Fleurance, G., Duncan, P., Fritz, H., Gordon, I.J., Grenier-Loustalot, M.F., 2010. Influence of sward structure on daily intake and foraging behaviour by horses. Animal 4, 480-485.

Garcia, F., Carrère, P., Soussana, J.-F., Baumont, R., 2003. How do severity and frequency of grazing affect sward characteristics and the choices of sheep during the grazing season? Grass Forage Sci. 58, 138-150.

Gordon, I.J., 1989. Vegetation community selection by ungulates on the isle of Rhum III. Determinants of vegetation community selection. J. Appl. Ecol. 26, 65-79.

Grime, J.P., Hodgson, J.G., Hunt, R., 1988. Comparative plant ecology. A Functional Approach to Common British Species. Wiley, J. \& Sons, London, UK.

Holmquist, J.G., Schmidt-Gengenbach, J., Haultain, S.A., 2010. Does long-term grazing by pack stock in subalpine wet meadows result in lasting effects on arthropod assemblages? Wetlands 30, 252-262.

Holmquist, J.G., Schmidt-Gengenbach, J., Haultain, S.A., 2013. Equine grazing in managed subalpine wetlands: effects on arthropods and plant structure as a function of habitat. Environ. Manage. 52, 1474-1486.

Holmquist, J.G., Schmidt-Gengenbach, J., Ballenger, E.A., 2014. Patch-scale effects of equine disturbance on arthropod assemblages and vegetation structure in subalpine wetlands. Environ. Manage. 53, 1109-1118.

Hoste-Danylow, A., Romanowski, J., Zmihorski, M., 2010. Effects of management on invertebrates and birds in extensively used grassland of Poland. Agric. Ecosyst. Environ. 139, 129-133.

Hutchinson, K.J., King, K.L., 1980. The effects of sheep stocking level on invertebrate abundance, biomass and energy utilization in a temperate sown grassland. J. Appl. Ecol. 17, 369-387.

INRA, 2015. Equine Nutrition: INRA Nutrient Requirements, Recommended Allowances and Feed Tables. Wageningen Academic publisher, Wageningen.

Isselstein, J., Correll, O., Strodthoff, J., Zhao, G., Hofmann, M., 2003. Variability of sward structure and plant species composition of pastures at low stocking rates. Grassland Sci. Eur. 8, 606-609.

Jacobs, J., 1974. Quantitative measurements of food selection: a modification of the forage ratio and Ivlev's electivity index. Oecologia 14, 413-417.

Jeannel, R., 1941. Faune de France, Coléoptères carabiques, première partie. Fédération Française des Sociétés de Sciences Naturelles.

Jeannel, R., 1942. Faune de France, Coléoptères carabiques, deuxième partie. Fédération Française des Sociétés de Sciences Naturelles.

Jerrentrup, J.S., Wrage-Mönnig, N., Röver, K.-U., Isselstein, J., 2014. Grazing intensity affects insect diversity via sward structure and heterogeneity in a long-term experiment. J. Appl. Ecol. 51, 968-977.

Kati, V., Zografou, K., Tzirkalli, E., Chitos, T., Willemse, L., 2012. Butterfly and grasshopper diversity patterns in humid Mediterranean grasslands: the role of disturbance and environmental factors. J. Insect Conserv. 16, 807-818.

Kerguélen, M., Plonka, F., 1989. Les Festuca de la flore de France (Corse comprise) (Fescues of the flora of France, including Corsica), Bulletin de la Société Botanique du Centre-Ouest, no special 10. La Société Botanique du CentreOuest, Jarnac, France.

Klimek, S., Richter Gen Kemmermann, A., Hofmann, M., Isselstein, J., 2007. Plant species richness and composition in managed grasslands: the relative importance of field management and environmental factors. Biol. Conserv. 134, 559-570.

Kruess, A., Tscharntke, T., 2002. Grazing intensity and the diversity of grasshoppers butterflies, and trap-nesting bees and wasps. Conserv. Biol. 16, 1570-1580. 
Lazo, A., Soriguer, R.C., 1993. Size-biased foraging behaviour in feral cattle. Appl. Anim. Behav. Sci. 36, 99-110.

Littell, R.C., Henry, P.R., Ammerman, C.B., 1998. Statistical analyses of repeated measures data using SAS procedures. J. Anim. Sci. 76, 1216-1231.

Loucougaray, G., Bonis, A., Bouzille, J.-B., 2004. Effects of grazing by horses and/or cattle on the diversity of coastal grasslands in western France. Biol. Conserv. 116, 59-71.

Lukas, M., Südekum, K.-H., Rave, G., Friedel, K., Susenbeth, A., 2005. Relationship between faecal crude protein concentration and diet organic matter digestibility in cattle. J. Anim. Sci. 83, 1332-1344.

Ménard, C., Duncan, P., Fleurance, G., Georges, J.Y., Lila, M., 2002. Comparative foraging and nutrition of horses and cattle in European wetlands. J. Appl. Ecol. 39, 120-133.

Mésochina, P., Martin-Rosset, W., Peyraud, J.-L., Duncan, P., Micol, D., Boulot, S., 1998 Prediction of the digestibility of the diet of horses: evaluation of faecal indices. Grass Forage Sci. 53, 189-196.

Magnússon, B., Magnússon, S.H., 1990. Studies in the grazing of a drained lowland fen in Iceland: I. The responses of the vegetation to livestock grazing. Búvísindi Icel. Agric. Sci. 4, 87-108.

Marini, L., Fontana, P., Battisti, A., Gaston, K.J., 2009. Agricultural management, vegetation traits and landscape drive orthopteran and butterfly diversity in a grassland-forest mosaic: a multi-scale approach. Insect Conserv. Divers. 2, 213 220.

Marion, B., Bonis, A., Bouzillé, J.-B., 2010. How much does grazing-induced heterogeneity impact plant diversity in wet grasslands? Écoscience 17, 1-11.

Marriott, C.A., Fothergill, M., Jeangros, B., Scotton, M., Loault, F., 2004. Long-term impacts of extensification of grassland management on biodiversity and productivity in upland areas. A review. Agronomie 24, 447-462.

Marriott, C.A., Bolton, G.R., Fisher, J.M., Hood, K., 2005. Short-term changes in soil nutrients and vegetation biomass and nutrient content following the introduction of extensive management in upland sown swards in Scotland, UK. Agric. Ecosyst. Environ. 106, 331-344.

Nolte, S., Esselink, P., Bakker, J.P., 2013. Flower production of Aster tripolium is affected by behavioral differences in livestock species and stocking densities: the role of activity and selectivity. Ecol. Res. 28, 821-831.

Nolte, S., Esselink, P., Smit, C., Bakker, J.P., 2014. Herbivore species and density affect vegetation-structure patchiness in salt marshes. Agric. Ecosyst. Environ. 185, $41-47$.
O’Neill, K.M., Olson, B.E., Rolston, M.G., Wallander, R., Larson, D.P., Seibert, C.E., 2003. Effects of livestock grazing on rangeland grasshopper (Orthoptera: Acrididae) abundance. Agric. Ecosyst. Environ. 97, 51-64.

Parsons, A.J., Chapman, D.F., 1999. The principles of pasture growth and utilization, In: Hopkins, A. (Ed.), Grass: Its Production and Utilization. 3rd edition Blackwell Science The British Grassland Society, Oxford, pp. 31-89.

Rosa Garcia, R., Fraser, M.D., Celaya, R., Ferreira, L., Garcia, U., Osoro, K., 2013. Grazing land management and biodiversity in the Atlantic European heathlands: a review. Agrofor. Syst. 87, 19-43.

Schlegel, M.L., Wachenheim, C.J., Benson, M.E., Ames, N.K., Rust, S.R., 2000. Grazing methods and stocking rates for direct-seeded alfalfa pastures: II: pasture quality and diet selection. J. Anim. Sci. 78, 2202-2208.

Scohier, A., Dumont, B., 2012. How do sheep affect plant communities and arthropod populations in temperate grasslands? Animal 6, 1129-1138.

Stewart, G.B., Pullin, A.S., 2008. The relative importance of grazing stock type and grazing intensity for conservation of mesotrophic 'old meadow' pasture. J. Nat. Conserv. 16, 175-185.

Taylor, E.L., 1954. Grazing behaviour and helminthic disease. Brit. J. Anim. Behav. 2, 61-62.

Ten Harkel, M.J., Van der Meulen, F., 1995. Impact of grazing and atmospheric nitrogen deposition on the vegetation of dry coastal dune grasslands. J. Veg. Sci. 6, 445-452.

Tscharntke, T., Greiler, H.J., 1995. Insect communities, grasses and grasslands. Annu. Rev. Entomol. 40, 535-558.

Tutin, M.T.G., Heywood, V.H., Burges, N.A., Moore, D.M., Valentine, D.H., Walters, S. Webb, D.A., 1964. Flora Europaea, vols. 1-5. Cambridge University Press, Cambridge, UK.

Van Soest, P.J., Robertson, J.B., Lewis, B.A., 1991. Methods for dietary fiber, neutral detergent fiber, and nonstarch polysaccharides in relation to animal nutrition. J. Dairy Sci. 74, 3583-3597.

Vulink, J.T., Drost, H.J., Jans, L., 2000. The influence of different grazing regimes on Phragmites-shrub vegetation in the well-drained zone of a eutrophic wetland. Appl. Veg. Sci. 2, 73-80.

Wallis de Vries, M.F., Parkinson, A.E., Dulphy, J.P., Sayer, M., Diana, E., 2007. Effects of livestock breed and grazing intensity on biodiversity and production in grazing systems. 4. Effects on animal diversity. Grass Forage Sci. 62, 185-197.

White, T.A., Barker, D.J., Moore, K.J., 2004. Vegetation diversity, growth, quality and decomposition in managed grasslands. Agric. Ecosyst. Environ. 101, 73-84. 